(C) Weed Science Society of America, 2017. This is an Open Access article, distributed under the terms of the Creative Commons Attribution licence (http://creativecommons.org/licenses/by/4.0/), which permits unrestricted re-use, distribution, and reproduction in any medium, provided the original work is properly cited.

\title{
Controlling Dinitroaniline-Resistant Goosegrass (Eleusine indica) in Turfgrass
}

\author{
Shane M. Breeden, James T. Brosnan, Gregory K. Breeden, Jose J. Vargas, Gregor Eichberger, \\ Stefan Tresch, and Martin Laforest*
}

Prodiamine is a dinitroaniline herbicide labeled for PRE control of goosegrass in warm- and cool-season turfgrass. In 2013, several golf course roughs in Maryville, TN reported poor goosegrass control $(<20 \%)$ following prodiamine treatment at $1,120 \mathrm{~g}$ ai $\mathrm{ha}^{-1}$. We harvested suspected prodiamine-resistant $(\mathrm{PR})$ and prodiamine-susceptible $(\mathrm{S})$ goosegrass phenotypes from the field and exposed them to a range of increasing prodiamine concentrations in hydroponic culture. Exposure to prodiamine at $0.001 \mathrm{mM}$ reduced root growth of the $S$ phenotype to $11 \%$ of the non-treated check. By comparison, exposure to $0.001 \mathrm{mM}$ prodiamine had minimal effect on the PR phenotype, as root growth was $94 \%$ of the non-treated check. Molecular analyses revealed that PR plants contained a threonine (Thr) to isoleucine (Ile) substitution at position 239 on the $\alpha$-tubulin 1 (TUA1) protein. The substitution, found in all PR plants, is the mechanism of prodiamine resistance in this phenotype. In field studies, topramezone controlled PR goosegrass $72 \%$ to $89 \%$ by 50 $\mathrm{d}$ after treatment (DAT) compared to only $22 \%$ to $23 \%$ for foramsulfuron. Topramezone treatment injured bermudagrass $34 \%$ to $60 \%$ from 7 to 14 DAT; however, injury was $\leq 6 \% 28$ DAT and $0 \%$ by the end of the study. Our results indicate that POST applications of topramezone can control dinitroaniline-resistant goosegrass. In addition, we established an easy-to-use genotyping assay to quickly screen goosegrass phenotypes for a target-site mutation (Thr-239-Ile) on TUA1 associated with resistance to dinitroaniline herbicides such as prodiamine. Future research should work to expand this assay for use with other weed species and herbicidal modes of action.

Nomenclature: Foramsulfuron; prodiamine; topramezone; goosegrass, Eleusine indica L. Gaertn.; bermudagrass, Cynodon dactylon L. Pers.

Key words: Herbicide resistance, hydroxyphenyl-pyruvate-dioxygenase (HPPD), mitotic inhibitor, target-site resistance

Goosegrass is a summer annual weedy grass that is problematic throughout warm- and cool-season turfgrass (McCullough et al. 2013). Goosegrass infestations often occur at sites with compacted soils lacking in turf cover (Arrieta et al. 2009). Goosegrass germination is stimulated by fluctuating air temperature and light, with optimal germination observed following $16 \mathrm{~h}$ at $20^{\circ} \mathrm{C}$ and $8 \mathrm{~h}$ at $35^{\circ} \mathrm{C}$ with light (Nishimoto and McCarty 1997). Dinitroaniline herbicides such as prodiamine and pendimethalin are frequently used PRE to control annual weeds such as goosegrass in managed turfgrass systems. These herbicides prevent microtubule polymerization in cells of susceptible species by binding to the globular protein tubulin (Vaughn et al. 1991). This mechanism consequently prevents sister chromatids from segregating during the anaphase portion of mitosis, causing discontinuation of cell division (Senseman 2007).

Goosegrass resistance to dinitroaniline herbicides has been attributed to substitution of threonine for isoleucine at position 239 on $\alpha$-tubulin (Yamamoto et al. 1998; Anthony et al. 1998). Goosegrass phenotypes with resistance to dinitroaniline herbicides have been regularly reported throughout the southeastern United States. For example, Mudge et al. (1984) identified goosegrass phenotypes resistant to benefin, ethalfluralin, fluchloralin, isopropalin, oryzalin,

DOI: $10.1017 /$ wet.2017.57

* First, second, third, and fourth authors: Former Graduate Research Assistant, Associate Professor, Extension Specialist, and Research Associate, University of Tennessee Institute of Agriculture, 2431 Joe Johnson Drive, Knoxville, TN 37996; Fifth and sixth authors: Bioscience Researchers, BASF Corporation, 67056 Ludwigshafen am Rhein, Germany; Seventh author: Researcher. Saint-Jean-surRichelieu R\&D Centre, Quebec J3B 3E6, Canada. Corresponding author's E-mail: jbrosnan@utk.edu 
pendimethalin, and trifluralin in seven counties of northeastern South Carolina. Since then, there have been several reports of annual bluegrass (Poa annua L.) developing resistance to dinitroaniline herbicides following consecutive years of prodiamine applications for PRE weed control (Brosnan et al. 2014; Cutulle et al. 2009; Isgrigg et al. 2002). Recently, McCullough et al. (2013) identified a goosegrass phenotype on a golf course in Georgia that was resistant to the dinitroaniline herbicide prodiamine but was effectively controlled with single and sequential PRE applications of indaziflam or oxadiazon. However, options for POST control of prodiamine-resistant (PR) goosegrass were not investigated.

Topramezone, a hydroxyphenyl-pyruvate-dioxygenase inhibitor, is a pyrazole herbicide labeled for POST

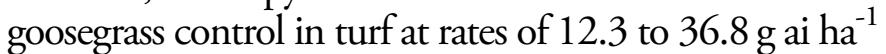
(Anonymous 2015). Cox et al. (2017) reported effective control of 8- to 18-tiller goosegrass with sequential topramezone applications at 6.1 or $12.3 \mathrm{~g} \mathrm{ai} \mathrm{ha}^{-1}$ on a 3 -week interval. Foramsulfuron is an acetolactate synthase-inhibiting herbicide labeled for POST goosegrass control (Anonymous 2006). Busey (2004) reported effective control of mature (i.e., 3- to 10-tiller) goosegrass in south Florida with tank mixtures of foramsulfuron and metribuzin. Brosnan et al. (2008) reported that foramsulfuron at $0.045 \mathrm{~kg}$ ai ha ${ }^{-1}$ controlled a population of goosegrass resistant to the photosystem II inhibitors metribuzin and simazine. Topramezone and foramsulfuron may provide turf managers with options for controlling dinitroanilineresistant goosegrass POST. However, data on this subject are limited.

In the summer of 2013, poor goosegrass control $(<20 \%)$ was reported on several golf course roughs at Lambert Acres Golf Course in Maryville, TN $\left(35.747307^{\circ} \mathrm{N},-83.884067^{\circ} \mathrm{W}\right)$ following prodiamine treatment at $1,120 \mathrm{~g}$ ai ha ${ }^{-1}$. Course managers had applied prodiamine exclusively in this manner for residual weed control for $>11$ consecutive years at this location (J.D. Murr, personal communication). Additionally, populations of PR annual bluegrass have already been identified at this golf course (Brosnan et al. 2014). A finding that goosegrass at this location is resistant to prodiamine would mark the first documented occurrence in Tennessee of goosegrass developing resistance to prodiamine. Thus, our objectives were to (1) determine the sensitivity of a putative PR goosegrass phenotype collected from this location, (2) elucidate the mechanism of resistance in this phenotype, and (3) identify options for effective POST control of this phenotype in the field.

\section{Materials and Methods}

\section{Glasshouse Studies Confirming Resistance.}

Mature goosegrass plants suspected of being resistant to prodiamine (hereafter referred to as PR) were harvested from roughs at Lambert Acres Golf Club (Maryville, TN) during July 2013 with a tubular plugger (Turf Tec International, Tallahassee, FL 32303). Turf at this location was an unknown cultivar of common bermudagrass that had been treated with prodiamine at $1,120 \mathrm{~g} \mathrm{ha}^{-1}$ during February 2013. A mature goosegrass phenotype known to be susceptible to prodiamine (hereafter referred to as $S$ ) was harvested from bermudagrass golf course roughs at Bay's Mountain Golf (Seymour, $\mathrm{TN} ; 35.51^{\circ} \mathrm{N},-83.49^{\circ} \mathrm{W}$ ). Individual tillers of harvested $\mathrm{PR}$ and $\mathrm{S}$ plants were removed and transplanted into $164-\mathrm{cm}^{3}$ containers (SC10 Super Cell Conetainer. Steuwe \& Sons. Tangent, OR 97389) filled with a peat moss growing medium (Growing Mix \#2. Conrad Fafard, Inc., Agawam, MA 01001). A total of 700 single-tiller transplants (350 PR and $350 \mathrm{~S}$ ) were propagated from fieldharvested plants. These single-tiller transplants were maintained under controlled glasshouse conditions for several weeks before initiating research. During the acclimation period, plants were irrigated as needed to prevent moisture stress and clipped twice a week at a height of $-5 \mathrm{~cm}$. By the time glasshouse experiments were initiated, these transplants had matured such that all plants had a minimum of two tillers.

Sensitivity of the PR and $S$ phenotypes to prodiamine was confirmed using hydroponic methods of Brosnan et al. (2014) in a glasshouse at the University of Tennessee (Knoxville, TN; $35.564593^{\circ} \mathrm{N}$, $-83.561603^{\circ} \mathrm{W}$ ). Polyethylene containers (Rubbermaid Roughneck, Rubbermaid Commercial Products LLC, Winchester, VA) containing $10 \mathrm{~L}$ of a full-strength Hoagland solution (Hoagland and Arnon 1950) were aerated with a blower (Model VB-007S, Sweetwater, Ft. Collins, CO), air stones (HAGEN Elite 1-inch Cube Air Stone, Rolf C. Hagen Corp., Mansfield, MA), and Tygon tubing (Saint-Gobain Performance Plastics Akron, $\mathrm{OH}$ ). Into the lid of each container were drilled 10 holes of $0.4-\mathrm{cm}$ diameter at $5.3-\mathrm{cm}$ spacing. Thus, mean values for a single container were generated using 10 subsamples. 
Goosegrass plants were cleansed of media and transplanted into each container such that root tissues were submerged in the aerated nutrient solution. All plants were trimmed to a uniform root length of $6 \mathrm{~cm}$ to facilitate assessments of root growth in response to herbicide treatment.

Prodiamine (Barricade 65 WG, Syngenta Professional Products, Greensboro, NC) was added to the nutrient solution in each container at concentrations of $0,0.001,0.01,0.1$, and $1.0 \mathrm{mM}$ immediately after transplanting. The blower used to aerate each container provided enough agitation to prevent prodiamine from falling out of suspension in the container. Herbicides were placed into each container on August 19, 2013. During the entire first experimental run, maximum and minimum daily air temperatures were $30^{\circ} \mathrm{C}$ and $23^{\circ} \mathrm{C}$, with a daily light integral of $34 \mathrm{~mol} \mathrm{~m} \mathrm{~m}^{-2} \mathrm{~d}^{-1}$. At 10 days after treatment (DAT), goosegrass root length was measured on all PR and $S$ plants. Root length data were used to determine effects of prodiamine concentration on root growth (as a percentage of the non-treated check) using the following equation:

Root growth $(\%)=\left[\left(\right.\right.$ Root length ${ }_{10 \mathrm{DAT}}-6 \mathrm{~cm}$ trimming length $) /$

$\left(\right.$ Root length $_{\text {non-treated at } 10 \text { DAT }}-6 \mathrm{~cm}$ trimming length) $] \times 100$ (1)

Experiments were arranged in a randomized complete block design with three replications and repeated in time during 2013. The second experimental run was initiated on August 30, 2013. Observed maximum and minimum daily temperatures in the glasshouse during the second experimental run were also $30^{\circ} \mathrm{C}$ and $23^{\circ} \mathrm{C}$, with a daily light integral of $37 \mathrm{~mol} \mathrm{~m}^{-2} \mathrm{~d}^{-1}$.

All root growth data were subjected to statistical analysis using $\mathrm{R}$ software ( $\mathrm{R}$ version 3.3.1). Expected means squares of McIntosh (1983) determined that data could be combined over experimental runs before being subjected to ANOVA using the 'ExpDes' package in the $\mathrm{R}$ statistical platform. Root growth of the PR and $S$ phenotypes in response to increasing concentrations of prodiamine was compared using nonlinear regression techniques in Prism (Prism 5 for Mac OS X. GraphPad Software. La Jolla, CA). Responses for each phenotype were fit to a one-phase exponential decay model and compared using a global sums of squares F-test at $\alpha=0.05$.

Genetic Sequencing and Molecular Analysis. Genomic DNA was extracted with NucleoSpin ${ }^{\circledR}$
Plant II extraction kit (Macherey-Nagel, Düren, Germany) according to the manufacturer's instructions. Leaves of $S$ and PR goosegrass were harvested, lyophilized, and homogenized before DNA extraction. To amplify the $\alpha$-tubulin gene (TUA1) at the position mediating dinitronaniline herbicide resistance (Thr-239-Ile; Yamamoto et al. 1998; Anthony et al. 1998), PCR was carried out with KOD Hot Start DNA Polymerase (Merck Bioscience, Darmstadt, Germany) according to the manufacturer's instructions. The forward PCR primer for TUA1 was 5'-GTCTGTTGACTACGGCAAGAA3' (Tre 460), and the reverse primer was 5'CACTGGAGCGTAGGATGAAAG-3' (Tre 461). PCR started with initial denaturation at $95^{\circ} \mathrm{C}$ for $2 \mathrm{~min}$ followed by $95^{\circ} \mathrm{C}$ denaturation for $20 \mathrm{~s}$, annealing at $58^{\circ} \mathrm{C}$ for $10 \mathrm{~s}$, and elongation at $70^{\circ} \mathrm{C}$ for $15 \mathrm{~s}$. Denaturation, annealing, and elongation were repeated for 40 cycles. Sanger sequencing of PCR products was performed with a 3130xl Genetic Analyzer (Applied Biosystems, Thermo Fisher Scientific, Waltham, MA, USA) and BigDye ${ }^{\circledR}$ Terminator v3.1 cycle sequencing Kit (Thermo Fisher Scientific, Waltham, MA, USA) with DNA primers as mentioned above. DNA sequences for the PR and $S$ phenotypes are available in GenBank (MF094447, MF094446; NCBI 2017).

To allow fast- and medium-throughput analyses of leaf samples from multiple plants, a Taqman ${ }^{\circledR}$-based single-nucleotide polymorphism (SNP) genotyping assay was established. DNA oligos for SNP differentiation between the ACA (Thr) and ATA (Ile) codons were designed using custom Taqman ${ }^{\circledR}$ SNP genotyping service (Thermo Fisher Scientific, Waltham, MA, USA). The analyses were performed using a CFX RealTime PCR detection system (Bio-Rad, Hercules, VA, USA). A total volume of $20 \mu \mathrm{L}$, consisting of $2.5-\mu \mathrm{L}$ genomic DNA samples, $10 \mu \mathrm{L}$ SsoAdvancedTM Universal Probes Supermix (Bio-Rad, Hercules, VA, USA), $0.5 \mu \mathrm{L}$ flanking primers and probe mix, and $7 \mu \mathrm{L}$ water was added to the PCR wells (HardShell PCR Plates, 96-well; Bio-Rad, Hercules, VA, USA). Flanking primer sequences were the following: 5'-CCGTAACATGTGGTTGTTTCTTATGA-3' (ELEIN_mut_F) and 5'-ACGTTCAGAGCACC ATCGAA-3' (ELEIN_mut_R). The following probes were designed to overlap the wild-type or Thr-239-Ile variation in TUA1, respectively: 5'-CAGAGAGGCTGTCAGTG-3' (ELEIN_mut_ VIC) and 5'-CAGAGAGGCTATCAGTG-3' 
(ELEIN_mut_FAM) (Custom Taqman $^{\circledR}$ SNP Genotyping Assay Service, Thermo Fisher Scientific, Waltham, MA, USA). Samples analyzed by Sanger sequencing were used as homozygous susceptible or resistant controls. Real-time PCR was run using FAM as the fluorescent dye for the resistant gene with the Thr-239-Ile variation and VIC as the fluorescent dye for the wild type. Cycling conditions were as follows: polymerase activation at $95^{\circ} \mathrm{C}$ for $2 \mathrm{~min}$, denaturation at $95^{\circ} \mathrm{C}$ for $15 \mathrm{~s}$, followed by annealing and extension at $64^{\circ} \mathrm{C}$ for $30 \mathrm{~s}$, for a total of 70 cycles. Percentages of the resistant and wild-type variant were calculated based on the sum of fluorescence intensity VIC and FAM at PCR cycle 35.

Field Experiments. Field experiments were conducted at Lambert Acres Golf Course (Maryville, $\mathrm{TN}$ ) evaluating the efficacy of topramezone and foramsulfuron for POST control of PR goosegrass. Trials were conducted in 2013 and 2015 in a common bermudagrass rough maintained at $4.5 \mathrm{~cm}$. Soil was a Dewey silty clay loam (fine, kaolinitic, thermic typic Paleudults). The golf course rough site received no supplemental nutrition or irrigation aside from rainfall during the course of the study. This site had been treated with prodiamine at $1,120 \mathrm{~g} \mathrm{ha}^{-1}$ for 11 consecutive years before initiating research, including applications made in February 2013 and March 2015.

Herbicide treatments included topramezone (12.3, 24.5, and $36.8 \mathrm{~g} \mathrm{ha}^{-1}$ ) and foramsulfuron (29 and $\left.43.6 \mathrm{~g} \mathrm{ha}^{-1}\right)$. Both topramezone and foramsulfuron are labeled for POST goosegrass control in turf (Anonymous 2006, 2013). A non-treated check was included for comparison. Topramezone treatments included a methylated seed oil adjuvant at $0.625 \% \mathrm{v} / \mathrm{v}$. All treatments were applied POST in a water carrier to 1.2 by $1.8 \mathrm{~m}$ plots using a $\mathrm{CO}_{2}$-powered boom sprayer calibrated to deliver $281 \mathrm{~L} \mathrm{ha}^{-1}$ through 8002 flat-fan nozzles. Applications at each site were made on July 25, 2013 and July 6, 2015 to goosegrass plants that contained a minimum of 10 tillers at application.

Goosegrass control was visually assessed by means of a $0 \%$ (i.e., no control) to $100 \%$ (i.e., complete control) scale relative to the non-treated check at 7 , 14, 21, 28, 35, 42, and 50 DAT (Brown and Farmer 1991). Bermudagrass injury was assessed using a similar $0 \%$ to $100 \%$ scale relative to a non-treated check as well. Goosegrass plants present within a $1-\mathrm{m}^{2}$ grid placed in the center of each plot were counted to quantitatively confirm visual evaluations of goosegrass control at 50 DAT. This grid contained 100 squares measuring $0.01 \mathrm{~m}^{2}$.

Experimental design each year was a randomized complete block with six replications. Visual assessments of goosegrass control and bermudagrass injury were arcsine transformed before being subjected to ANOVA in SAS using the expected means squares of McIntosh (1983). No treatment-by-year interactions were detected, thus allowing data from each year to be combined. Interpretations of ANOVA using transformed data were not different from non-transformed assessments; therefore, non-transformed means are presented for clarity. Fisher's protected LSD test was used to separate treatment means at $\alpha=0.05$.

\section{Results and Discussion}

\section{Glasshouse Studies Confirming Resistance.}

Responses of the PR and S phenotypes to increasing concentrations of prodiamine were significantly different from one another (Figure 1). Exposure to prodiamine at $0.001 \mathrm{mM}$ reduced root growth of the $S$ phenotype to $11 \%$ of the non-treated check. Comparatively, exposure to $0.001 \mathrm{mM}$ prodiamine had minimal effect on the PR phenotype, as root growth was $94 \%$ of the non-treated by 10 DAT (Figure 1). A similar response, although with a more severe impact on the PR phenotype, was observed

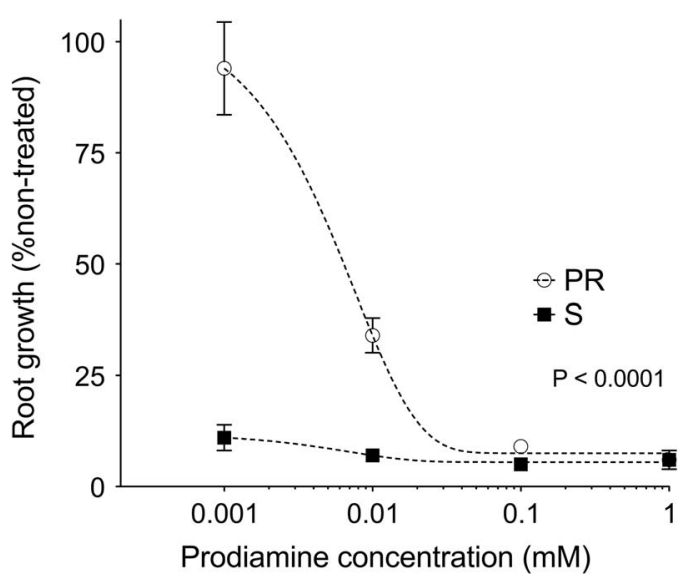

Figure 1. Root growth of prodiamine-resistant (PR) and susceptible (S) goosegrass (Eleusine indica L. Gaertn.) $10 \mathrm{~d}$ after treatment following exposure to increasing concentrations of prodiamine in hydroponic culture during glasshouse experiments in 2013. Root growth for the PR and $S$ phenotypes was expressed as a percentage of a non-treated check $(0 \mathrm{mM}$ prodiamine), with means generated using 10 subsamples per concentration, replicated six times over the course of two repeated experiments $(N=60)$. 
following exposure to $0.01 \mathrm{mM}$ prodiamine as well. Once prodiamine concentrations increased to $0.10 \mathrm{mM}$, no differences in root growth between the $\mathrm{PR}$ and $\mathrm{S}$ phenotypes were detected, as both measured $\leq 9 \%$ of their respective non-treated check (Figure 1). These whole-plant phenotypic assessments support field observations that the PR goosegrass phenotype from Tennessee is resistant to the dinitroaniline herbicide prodiamine.

To identify a possible target-site mutation causative for prodiamine resistance, part of the $\alpha$-tubulin 1 gene (TUA1) known to encode the binding site of dinitronanilines (Yamamoto et. al. 1998) was sequenced in both $\mathrm{PR}$ and $\mathrm{S}$ plants. The results showed that PR plants had a codon change from ACA to ATA, which corresponds to a threonine-toisoleucine substitution at position 239 in TUA1. A genotyping assay successfully detected that all PR plants (R1 to R10) were either homozygous (7) or heterozygous (3) for Thr to Ile, whereas all S plants only encoded Thr, the wild-type form of TUA1 susceptible to dinitroaniline herbicides (Table 1).

Table 1. Genotyping of prodiamine-resistant (PR) goosegrass plants for a threonine to isoleucine (Thr to Ile) substitution at position 239 on $\alpha$-tubulin 1 (TUA1).

\begin{tabular}{|c|c|c|c|}
\hline \multirow[b]{2}{*}{ Sample ID ${ }^{\mathrm{b}}$} & \multicolumn{2}{|c|}{$\begin{array}{c}\text { Single-nucleotide } \\
\text { polymorphisms present }(\%)^{\mathrm{a}}\end{array}$} & \multirow[b]{2}{*}{ Genotype } \\
\hline & $\begin{array}{c}\text { Resistant } \\
\text { codon (ATA) }\end{array}$ & $\begin{array}{l}\text { Wild-type } \\
\text { codon (ACA) }\end{array}$ & \\
\hline Susceptible control & 0.6 & 99.4 & Wild-type \\
\hline Resistant control & 93.5 & 6.5 & Homozygous \\
\hline S1 & 0.6 & 99.4 & Wild-type \\
\hline S2 & 0.6 & 99.4 & Wild-type \\
\hline S3 & 0.7 & 99.3 & Wild-type \\
\hline S4 & 0.9 & 99.1 & Wild-type \\
\hline S5 & 0.7 & 99.3 & Wild-type \\
\hline R1 & 99.9 & 0.1 & Homozygous \\
\hline R2 & 92.0 & 8.0 & Homozygous \\
\hline R3 & 99.9 & 0.1 & Homozygous \\
\hline $\mathrm{R} 4$ & 99.7 & 0.3 & Homozygous \\
\hline $\mathrm{R} 5$ & 48.3 & 51.7 & Heterozygous \\
\hline R6 & 93.1 & 6.9 & Homozygous \\
\hline R7 & 99.7 & 0.3 & Homozygous \\
\hline $\mathrm{R} 8$ & 93.1 & 6.9 & Homozygous \\
\hline R9 & 48.4 & 51.6 & Heterozygous \\
\hline $\mathrm{R} 10$ & 48.7 & 51.3 & Heterozygous \\
\hline
\end{tabular}

In combination with our whole-plant phenotyping and previously published results (Yamamoto et al. 1998; Anthony et al. 1998), we conclude that a target-site mechanism is responsible for resistance to prodiamine in PR goosegrass studied herein. Our genotyping assay clearly distinguishes between $S$, heterozygous resistant, and homozygous resistant plants and therefore is a useful diagnostic assay to detect target-site resistance to dinitronaniline herbicides in goosegrass. Yamamoto et al. (1998) introduced a technique to genotype the ACA-toATA mutation (prompting an amino acid change from Thr to Ile at position 239) in goosegrass using PCR primer-introduced restriction analysis that requires (a) amplification of the target sequence, (b) use of a restriction enzyme to cut the amplified fragments, (c) samples to be run on an agarose gel, and (d) a visual inspection of the gel to determine which allele is present. The TaqMan assay developed herein performs these operations in one step, where amplification of each allele is monitored together with real-time PCR and genotype can be automatically assigned at the end of amplification. Our approach is much faster, requires less hands-on time, and is easier to automate. Future research should be conducted to expand this assay for use with other weed species and different herbicide target sites.

\section{Field Experiments Evaluating POST Control.}

No significant treatment-by-year interactions were detected in goosegrass control or plant count data; therefore, data from each year were combined for analysis. Significant differences in goosegrass control due to herbicide treatment were detected 14, 28, and 50 DAT. Goosegrass control with topramezone was greater than foramsulfuron on all dates, with few significant differences detected among topramezone rates. By 50 DAT, topramezone controlled PR goosegrass $72 \%$ to $89 \%$ compared to only $22 \%$ to $23 \%$ for foramsulfuron (Table 2). Plant count data supported visual assessments of goosegrass control. Topramezone reduced goosegrass plant counts $60 \%$ to $83 \%$ compared to only $6 \%$ to $19 \%$ for foramsulfuron (Table 2). Cox et al. (2017) reported similar responses with POST applications of topramezone to herbicide-susceptible goosegrass at four locations in Virginia, with sequential treatments at $12.3 \mathrm{~g}$ ai ha ${ }^{-1}$ resulting in an $86 \%$ reduction in goosegrass cover $56 \mathrm{~d}$ after initial treatment. Poor goosegrass control with foramsulfuron in this 
Table 2. Prodiamine-resistant (PR) goosegrass control and plant count reductions following topramezone and foramsulfuron applications at Lambert Acres Golf Club (Maryville, TN). Means were combined from separate trials conducted in 2013 and 2015.

\begin{tabular}{|c|c|c|c|c|c|}
\hline \multirow[b]{2}{*}{ Herbicide } & \multirow[b]{2}{*}{ Rate } & \multicolumn{3}{|c|}{ Goosegrass control } & \multirow[b]{2}{*}{ Plant count ${ }^{b}$} \\
\hline & & $14 \mathrm{DAT}^{\mathrm{a}}$ & 28 DAT & $50 \mathrm{DAT}$ & \\
\hline & $\mathrm{g} \mathrm{ha}^{-1}$ & & $-\%-$ & 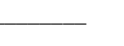 & $\%$ Reduction \\
\hline \multirow[t]{2}{*}{ Foramsulfuron } & 29 & 21 & 17 & 23 & 6 \\
\hline & 43.6 & 25 & 24 & 22 & 19 \\
\hline \multirow[t]{3}{*}{ Topramezone $^{c}$} & 12.3 & 67 & 82 & 72 & 60 \\
\hline & 24.5 & 68 & 94 & 86 & 83 \\
\hline & 36.8 & 74 & 97 & 89 & 83 \\
\hline $\mathrm{LSD}_{0.05}$ & & 9 & 16 & 14 & 29 \\
\hline
\end{tabular}

${ }^{a}$ Abbreviation: DAT, days after treatment.

b Plant count data were collected using a $1 \mathrm{~m}^{2}$ grid 50 DAT and expressed as a percent reduction relative to the non-treated check.

c All topramezone treatments included a methylated seed oil adjuvant at $0.625 \% \mathrm{v} / \mathrm{v}$.

experiment supports previous reports by Busey (2004) that multiple POST applications of foramsulfuron are required to control goosegrass.

Whereas topramezone effectively controlled PR goosegrass in these studies, applications also caused significant bermudagrass injury 7 and 14 DAT (Table 3). During this time frame, topramezone injured bermudagrass $34 \%$ to $60 \%$ compared to only $0 \%$ to $4 \%$ for foramsulfuron. Injury with the $12.3 \mathrm{~g} \mathrm{ha}^{-1}$ application rate was less than the 24.5 and $36.8 \mathrm{~g} \mathrm{ha}^{-1}$ application rates at 14 DAT. Topramezone injury may be unacceptable to turf managers; however, this response was transient, as

Table 3. Bermudagrass injury following topramezone and foramsulfuron applications at Lambert Acres Golf Club (Maryville, TN). Means were combined from separate trials conducted in 2013 and 2015.

\begin{tabular}{|c|c|c|c|c|c|}
\hline \multirow[b]{2}{*}{ Herbicide } & \multirow[b]{2}{*}{ Rate } & \multicolumn{4}{|c|}{ Bermudagrass injury } \\
\hline & & $7 \mathrm{DAT}^{\mathrm{a}}$ & $14 \mathrm{DAT}$ & 28 DAT & 50 DAT \\
\hline & $\mathrm{g} \mathrm{ha}^{-1}$ & & & & \\
\hline \multirow[t]{2}{*}{ Foramsulfuron } & 29 & 3 & 1 & 0 & 0 \\
\hline & 43.6 & 4 & 3 & 0 & 0 \\
\hline \multirow[t]{3}{*}{ Topramezone $^{\mathrm{b}}$} & 12.3 & 34 & 43 & 1 & 0 \\
\hline & 24.5 & 42 & 58 & 6 & 0 \\
\hline & 36.8 & 40 & 60 & 6 & 0 \\
\hline $\mathrm{LSD}_{0.05}$ & & 8 & 9 & NS & NS \\
\hline
\end{tabular}

${ }^{a}$ Abbreviations: DAT, days after treatment; NS, nonsignificant at $\alpha=0.05$.

b All topramezone treatments included a methylated seed oil adjuvant at $0.625 \% \mathrm{v} / \mathrm{v}$. injury was $\leq 6 \% 28$ DAT and $0 \%$ by 50 DAT. These responses support previous findings by Elmore et al. (2011), Brosnan et al. (2011), and Cox et al. (2017) following topramezone applications to bermudagrass. By 21 DAT in a glasshouse, topramezone applications at 18 to $38 \mathrm{~g} \mathrm{ha}^{-1}$ injured 'Tifway' hybrid bermudagrass $35 \%$ to $40 \%$ and 'Riviera' common bermudagrass $46 \%$ to $58 \%$ (Brosnan et al. 2011; Elmore et al. 2011). This injury was characterized as visual bleaching and accompanied by reductions in chlorophyll and carotenoid pigments in both grasses. However, both researchers reported that bermudagrass injury following topramezone treatment was negligible by 35 DAT (Brosnan et al. 2011; Elmore et al. 2011). Similarly, topramezone at $12.3 \mathrm{~g}$ ai $\mathrm{ha}^{-1}$ resulted in 31 bermudagrass varieties being injured $\geq 30 \%$ for an average of $13.8 \mathrm{~d}$ (Cox et al. 2017); however, injury was transient.

Our results indicate the first incidence of a PR goosegrass phenotype in Tennessee. Resistance at this location probably developed after repeated use of prodiamine for residual weed control for $>11$ consecutive years. An amino acid substitution from Thr to Ile at position 239 in TUA1 was identified as the most likely mechanism of resistance in this phenotype. POST applications of topramezone at $\geq 24.5 \mathrm{~g} \mathrm{ha}^{-1}$ effectively ( $86 \%$ to $89 \%$ ) controlled this PR goosegrass phenotype; however, transient bermudagrass injury observed after application may be unacceptable to certain turf managers. The genotyping assay described herein clearly differentiated between $S$ and PR plants and could be used as a diagnostic assay to detect target-site resistance to dinitronaniline herbicides in goosegrass populations from other locations.

\section{Acknowledgments}

The authors would like to thank the superintendent at Lambert Acres Golf Course, J.D. Murr, for his assistance with this project, as well as Tyler Campbell, Daniel Farnsworth, James Greenway, Eric Reasor, and Veronica Sublett. Drs. Thomas Mueller and Scott Senseman also contributed to this manuscript. Mention of trade names or commercial products in this publication is solely for the purpose of providing specific information and does not imply recommendation or endorsement by the University of Tennessee Institute of Agriculture. 


\section{Literature Cited}

Anonymous (2015) Pylex Herbicide Label. Research Triangle Park, NC: BASF Corporation. $10 \mathrm{p}$

Anonymous (2006) Revolver Herbicide Label. Research Triangle Park, NC: Bayer Environmental Sciences. $10 \mathrm{p}$

Anthony RG, Waldin TR, Ray JA, Bright SWJ, Hussey PJ (1998) Herbicide resistance caused by spontaneous mutation of the cytoskeletal protein tubulin. Nature 393:260-263

Arrieta C, Busey P, Daroub SH (2009) Goosegrass and bermudagrass competition under compaction. Agron J 101:11-16

Brosnan JT, Kopsell DA, Elmore MT, Breeden GK, Armel GR (2011) Changes in 'Riviera' bermudagrass [Cynodon dactylon (L.) Pers.] carotenoid pigments after treatment with three p-hydroxyphenylpyruvate dioxygenase-inhibiting herbicides. HortScience 46:493-498

Brosnan JT, Nishimoto RK, DeFrank J (2008) Metribuzinresistant goosegrass (Eleusine indica) in bermudagrass turf. Weed Technol 22:675-678

Brosnan JT, Reasor EH, Vargas JJ, Breeden GK, Kopsell DA, Cutulle MA, Mueller TC (2014) A putative prodiamineresistant annual bluegrass (Poa annua) population is controlled by indaziflam. Weed Sci 62:138-144

Brown RA, Farmer D (1991) Track-sprayer and glasshouse techniques for terrestrial plant bioassays with pesticides. Pages 197-208 in Gorsuch JW, Lower WR, Wang W \& Lewis MA eds, Plants for Toxicity Assessment. 2nd vol, ASTM STP 1115. Philadelphia, PA: American Society for Testing and Materials

Busey P (2004) Goosegrass (Eleusine indica) control with foramsulfuron in bermudagrass (Cynodon spp.) turf. Weed Technol 18:634-640

Cox MC, Rana SS, Brewer JR, Askew SD (2017) Goosegrass and bermudagrass response to rates and tank mixtures of topramezone and triclopyr. Crop Sci 57:1-12

Cutulle M, McElroy JS, Millwood RW, Sorochan JC, Stewart CN (2009) Selection of bioassay method influences detection of annual bluegrass resistance to mitotic-inhibiting herbicides. Crop Sci 49:1088-1095
Elmore MT, Brosnan JT, Kopsell DA, Breeden GK, Mueller TC (2011) Response of hybrid bermudagrass (Cynodon dactylon $\times C$. transvaalensis) to three HPPD-inhibitors. Weed Sci 59:458-463

Hoagland DR, Arnon DI (1950) The water-culture method for growing plants without soil. Berkeley, CA: California Agricultural Experiment Station Circular. 347:32 p

Isgrigg J III, Yelverton FH, Brownie C, Warren LS (2002) Dinitroaniline resistant annual bluegrass in North Carolina. Weed Sci 50:86-90

McCullough PE, Yu J, Gomez de Barreda D (2013) Efficacy of preemergence herbicides for controlling a dinitroaniline resistant goosegrass in Georgia. Weed Technol. 27:639-644

McIntosh MS (1983) Analysis of combined experiments. Agron J 75:153-155

Mudge LC, Gossett BJ, Murphy TR (1984) Resistance of goosegrass (Eleusine indica) to dinitroaniline herbicides. Weed Sci 32:591-594

[NCBI] National Center for Biotechnology Information (2017) GenBank Overview. Bethesda, MD: National Library of Medicine, MF Center for Biotechnology Information. https:// ncbi.nlm.nih.gov/genbank

Nishimoto RK, McCarty LB (1997) Fluctuating temperature and light influence goosegrass (Eleusine indica) seed germination. Weed Sci 45:426-429

Senseman SA (2007) Herbicide Handbook 9th edn, Lawrence, KS: Weed Science Society of America. Pp 11-14

Vaughn KC, Lehnen LP (1991) Mitotic disruptor herbicides. Weed Sci 39:450-457

Yamamoto E, Zeng L, Baird W (1998) Alpha-tubulin missense mutations correlate with antimicrotubule drug resistance in Eleusine indica. Plant Cell 10:297-308

Received March 6, 2017, and approved June 23, 2017.

Associate Editor for this paper: Scott McElroy, Auburn University. 